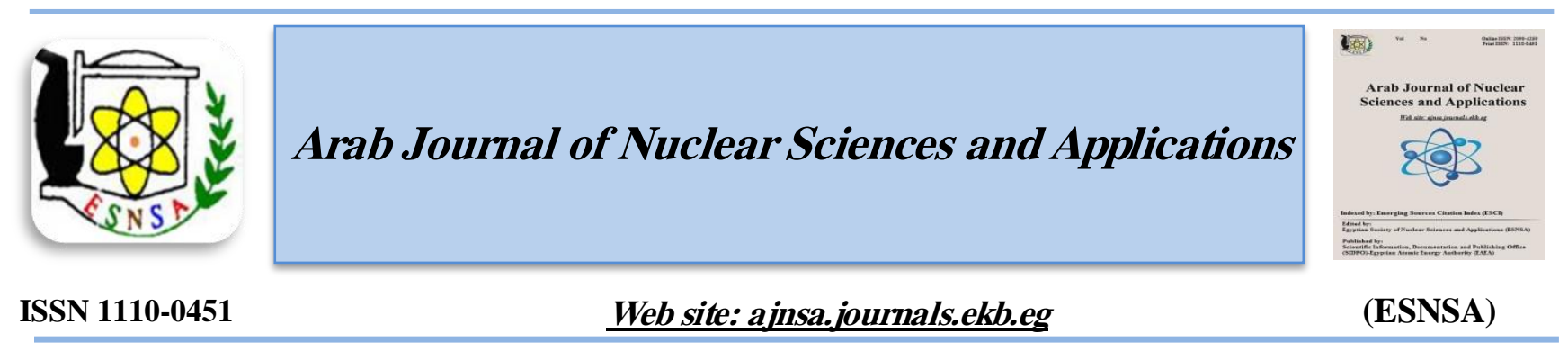

\title{
Determination of Radioactivity Concentration and Assessment of Absorbed Effective Dose of Edible Plant and Soil Samples
}

\author{
Mohammed Elywa \\ Biophysics Branch, Physics Department, Faculty of Science, Zagazig University, Egypt
}

Received $24^{\text {th }}$ Oct 2018 The aim of this study is the determination of radioactivity concentrations of naturally occurring $\mathrm{K}-40$, Accepted $24^{\mathrm{h}} \mathrm{Apr} 2019 \mathrm{U}-238$, and Th-232 and assessment of the annual effective dose of edible plant and its soil samples. The activity concentrations in soil and plant samples were measured using to HPGe-detector and analyzed using Genie2000 software. The radium equivalent, annual absorbed effective dose, indoor, outdoor absorbed dose and hazard index (Hex, Hin and Iy) have been estimated for workers. The present study has shown that both the uptake and the activity concentrations of U-238 and Th-232 were significantly low in comparison with K-40 radionuclide in soil and edible plant samples. Interestingly, the results of this research have demonstrated that soil and plant samples, that have been collected from Sharqia governorate, exhibited low activity concentration of radionuclides. Moreover, this decline in the activity concentration of radionuclides is below the worldwide values [1]. Taken together, the results of the present investigation on Radium equivalent, annual absorbed effective dose, indoor, outdoor absorbed dose, and hazard index $\left(H_{\text {ex }}, H_{\text {in }}\right.$ and $\left.I y\right)$ provide compelling evidence that the soil has low U-238, Th-232 and $\mathrm{K}-40$ concentration. Based on the present data, it is tempting to conclude that there is no health risk for eating these edible plants.

Keywords: Gamma ray spectroscopy/ Edible plants/ Hazard index/ Annual absorbed effective dose

\section{Introduction}

Determination of the radioactivity concentrations of U-238, Th-232 and K-40 in edible plants and their soil is the aim of this study. The transfer of the above radionuclides from soil to plants is considered to be a source of radiation exposure to the population [2]. Sharqia is the most important agriculture Governorate in Egypt, and is considered a source of crops production. Vegetables and beans (white bean, red bean cucumber and zucchini) are the most favorite foods for the Egyptian community. The transfer factor of these crops has been demonstrated or detected and reported in a previous study [3]. It was documented that white bean plant has the highest activity, where, Zucchini plant has minimal activity concentration. Exposure to pollution and transmission of radiation to food is one of the most important risks to people in Egypt. The current study demonstrates that the dose assessment exceeds the annual dose limit of $1 \mathrm{mSv}$ set for the population [4]. The results were compared to the data that has been reported by the United Nations Scientific Committee on the Effects of Radiation (UNSCEAR) [5].

The reported values of U-238 and Th-232 and K40 concentrations in various plant species differ significantly. The natural difference in the ability of plants to uptake radionuclides is not the only reason for such a situation. Certain contribution may be provided by methodologies of plant sampling and preparation and the various 
analytical techniques that used for determination of very low $\mathrm{U}$, Th and their decay products concentrations in the leaves of plant samples and also depends on the plant part (roots, leaves and shoots). Plants grown in radionuclide-enriched soils confirmed an increase in the concentration of Th-232 and U-238 in roots, while concentrations of the radionuclides in upper plant parts were rather low. Th-232 was less available to plant uptake than U-238 [6].

In addition, the transfer factor (TF) is utilized to determine the radionuclides' uptake from soil to the plants and is used for calculating the radiological human hazard via the ingestion pathway [7]. However, wild plants are more contaminated than vegetables produced in farms; the vegetables are the main food products around the world, the activity concentrations of naturally occurring and anthropogenic radionuclides deposited in the soil and especial crops such as rice [8]. Thus, the transfer factor is regarded as one of the most important environmental parameters for safety assessment for nuclear facilities [9].

Edible plants studied in the area around the Fukushima Daiichi nuclear power plant which remains contaminated where the crops with radiation contamination examined for the agriculture soil in different areas in Japan $[10,11]$. After the Chernobyl catastrophe, many of scientific research work have been performed by studying the soil plant transfer coefficients for many radioisotopes such as Cs-137 [12].

\section{Materials and Methods}

Study area

Figureure 1: shows the Sharqia Government map inwhich the samples were collected. Sharqia is one of the northern governorates in Egypt. There are many crop plants in this area; and vegetables are the most dominant products beside rice. The farmers (workers) affected by the radiation that are released from both soil and plants.

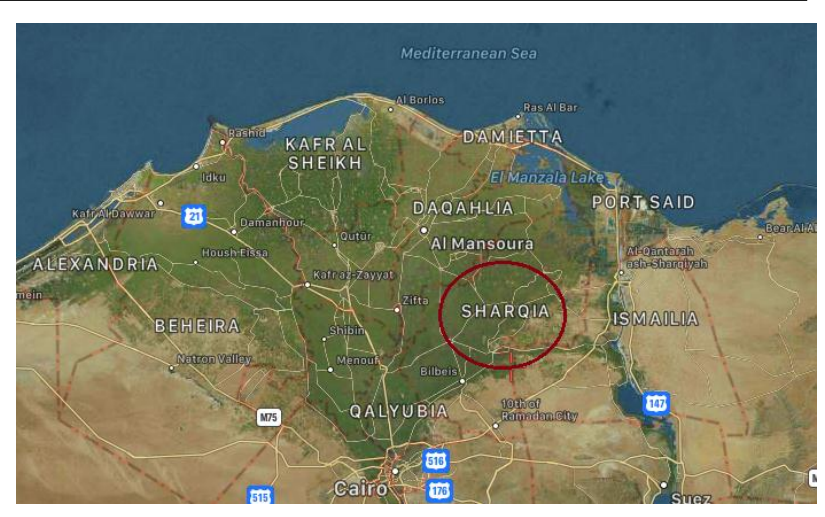

Figure (1): Sharqia Government (the study area) Samples collection

Phaseolus vulgaris (white beans and red beans), Cucumis sativus (Cucumber) and Cucurbita pepo (Zucchini)) and their soil samples (5 centimeters depth soil cores) were collected from many locations in Sharqia governorate. Four edible plant samples in the growth stage, leaves were collected from each location.

\section{Samples preparation and measurement}

Soil samples were well mixed after removing unrelated materials such as pieces of stone, mat portions and roots. Then, they were dried in an oven at $378{ }^{\circ} \mathrm{K}\left(105^{\circ} \mathrm{C}\right)$ for about 24 hours to remove the water and moisture until a constant dry mass was obtained and hence manually grinded. The leaves of plant samples were washed with fresh water for removing the mud and dust, cut into small pieces and primarily dried by spreading in air for about three days. Then they were dried in an electric oven at $60^{\circ} \mathrm{C}$ until friable stage. By using a grinder, the dried samples were ground into fine powder. Twenty soil and plant samples (five samples of each plant kind) were packed in plastic cylindrical containers of uniform size. All samples kept for more than four weeks to attain secular equilibrium between $\mathrm{Ra}-226$ and its progenies to be achieved before gamma spectroscopy.

\section{Analysis}

Gamma spectrometry a P-type coaxial HPGe detector (Canberra model: CPVD 30-3020, shielded by $10 \mathrm{~cm} \mathrm{~Pb}$ thickness, $1 \mathrm{~mm} \mathrm{Cd}$ and 1 $\mathrm{mm} \mathrm{Cu}$ ) with a relative efficiency of $30 \%$ and a resolution full width at half maximum (FWHM) of $2.1 \mathrm{keV}$ at $1.33 \mathrm{MeV}$ connected to multi-channel analyzer (MCA) and coupled with software program Genie 2000, was used. Efficiency calibration of the system was carried out by using secondary standard sources (RGU-1, $400 \mu \mathrm{g} / \mathrm{g}$ of 
U-238) and (RGTh-1, $800 \mu \mathrm{g} / \mathrm{g}$ of Th-232) produced from IAEA. The activity of $238 \mathrm{U}$ and 232Th was determined via their decay products: 214Bi $(609,1120$ and $1764 \mathrm{keV}), 214 \mathrm{~Pb}$ (352 and $295 \mathrm{keV}$ ) and 228Ac (338 and $911 \mathrm{keV}$ ), respectively. $238 \mathrm{U}$ was determined via234Pa $(\mathrm{t} 1 / 2=1.17 \mathrm{~min}, 1001 \mathrm{keV})$. The activity concentration of $40 \mathrm{~K}$ was determined depending on its $1460 \mathrm{keV}$ Gamma-energy. For background measurements pure silica was also poured to similar jar up to the same height as sample. Gamma spectrum for each sample and background were accumulated for about $24 \mathrm{~h} \mathrm{[13].}$

\section{Radium equivalent index}

Comparison between the specific activities of materials containing U-238, Th-232 and K-40 that was achieved by using the radium equivalent $\left(\mathrm{Ra}_{\mathrm{eq}}\right)$ illustrates the sum of activities of $\mathrm{U}-238$, Th-232 and $\mathrm{K}-40$, radionuclides where $1 \mathrm{Bqkg}^{-1}$ of $\mathrm{Ra}-226,0.7 \mathrm{~Bq} \mathrm{~kg}{ }^{-1}$ of Th-232, and $13 \mathrm{~Bq} \mathrm{~kg}^{-1}$ of $\mathrm{K}-$ 40 produce the same radiation dose rates [5].

$\mathrm{Ra}_{\mathrm{eq}}=\mathrm{C}_{\mathrm{Ra}}+1.43 \mathrm{C}_{\mathrm{Th}}+0.077 \mathrm{C}_{\mathrm{k}}$

Where $\mathrm{C}_{\mathrm{Ra}}, \mathrm{C}_{\mathrm{Th}}$ and $\mathrm{C}_{\mathrm{K}}$ are the radioactivity concentration in $\mathrm{Bq} / \mathrm{kg}$ of $\mathrm{U}-238$, Th-232, and $\mathrm{K}-$ 40.

\section{Absorbed dose rate calculation}

The external gamma dose rate at $1 \mathrm{~m}$ above the ground (D) in air was calculated from the measured activity concentration of U-238, Th-232 and K-40 in edible plants and their soil samples. The calculations were performed according to the following equation [14].

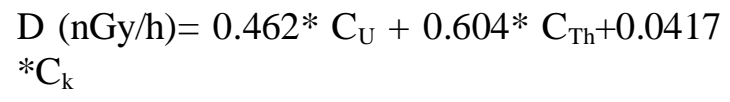

Where $\mathrm{C}_{\mathrm{U}}, \mathrm{C}_{\mathrm{Th}}$, and $\mathrm{C}_{\mathrm{K}}$ are the activity concentrations of U-238, Th-232, and K-40 in $(\mathrm{Bq} / \mathrm{kg})$, respectively [15], and 0.462, 0.604 and 0.0417 dose conversion factor of U-238, Th-232, and $\mathrm{K}-40$ in $((n G y / h) /(B q / k g))$, respectively.

\section{Representative level index}

Representative level index, $1_{\gamma}$ is used to calculate approximately the hazard of gamma- radiation associated with the natural radionuclides. It is given as:
$1_{\mathrm{Y}}=\mathrm{C}_{\mathrm{Ra}} / 150+\mathrm{C}_{\mathrm{Th}} / 100+\mathrm{C}_{\mathrm{k}} / 1500$

Where $\mathrm{C}_{\mathrm{Ra}}, \mathrm{C}_{\mathrm{Th}}$ and $\mathrm{C}_{\mathrm{K}}$ are the radioactivity concentration in $\mathrm{Bq} / \mathrm{kg}$ of U-238, Th-232 and $\mathrm{K}$ 40. This gamma index is also used to correlate the annual dose rate due to the excess external gamma radiation [16].

\section{Effective dose}

To estimate the annual effective doses, both (i) the conversion coefficient from absorbed dose in air to effective dose and (ii) the indoor occupancy factor should be taken into account. In report of UNSCEAR [17], the Committee used $0.7 \mathrm{~Sv} / \mathrm{Gy}$ for the conversion coefficient from absorbed dose in air to effective dose received by adults and 0.8 for the indoor occupancy factor, i.e. the fraction of time spent indoors and outdoors is 0.8 and 0.2 , respectively. The components of the annual effective dose are determined as follows:

$$
\text { Indoor: } \mathrm{AED}(\mathrm{mSV})=\mathrm{D}(\mathrm{nGy} / \mathrm{h}) \times 8,760 \mathrm{~h}
$$$$
\text { x } 0.7 \mathrm{~Sv} / \mathrm{Gy} \text { x } 0.8
$$

Outdoor: AED $(\mathrm{mSV})=\mathrm{D}(\mathrm{nGy} / \mathrm{h}) \times 8,760$

$\mathrm{h} \times 0.7 \mathrm{~Sv} / \mathrm{Gy} \times 0.2$

Where AED is the effective dose measured in $\mathrm{mSV}$ and $\mathrm{D}$ is the Absorbed Dose Ratein(nGy/h).

\section{External hazard index}

The factors which determine the exposure rate of an individual are the concentration of radionuclides in the soil and the time spent outdoors. The external hazard index is an assumption that helps to evaluate the additional radiation hazard of natural gamma radiation. The External Hazard Index [18] is defined as:

$\mathrm{H}_{\mathrm{ex}}=\mathrm{C}_{\mathrm{Ra}} / 370+\mathrm{C}_{\mathrm{Th}} / 259+\mathrm{C}_{\mathrm{k}} / 4810$

The value of this index must be less than unity for the radiation hazard to be negligible. $\mathrm{H}_{\mathrm{ex}}=1$ is a corresponding quantity to the upper limit of $\mathrm{Ra}_{\mathrm{eq}}$ $(370 \mathrm{~Bq} / \mathrm{kg})$.

\section{Internal hazard index}

The internal hazard index $\left(\mathrm{H}_{\text {in }}\right)$ is given as

$\mathrm{H}_{\text {in }}=\mathrm{C}_{\mathrm{Ra}} / 185+\mathrm{C}_{\mathrm{Th}} / 259+\mathrm{C}_{\mathrm{k}} / 4810$

For the radiation hazard $\mathrm{H}_{\text {in }}$ has to be negligible, $\mathrm{H}_{\text {in }}<1$. 
The activity concentration (A) of each radionuclide in the soil and plant samples were determined by using the net count rates $N_{\text {net }}$ fter subtracting the background counts (BG) from the gross counts for the same counting time under the selected photo peaks, Equation 7 used for calculation [18];

$A=\frac{N_{\text {net }}}{\varepsilon * I_{\gamma} * m} B q / k g$

Where, $\mathrm{A}=$ the activity concentration of the sample. $N_{\text {net }}$ is the total counts per second from the samples - background counts per second. $\varepsilon=$ the efficiency of the detector for the specific energy. $\quad I \gamma=$ the intensity of the gamma ray. $\mathrm{m}=$ Sample mass in g. A computer software programming (GENIE 2000) used to analyze the acquired spectra.

The activity concentrations of U-238 and Th-232 series and $\mathrm{K}-40$ measured in $(\mathrm{Bq} / \mathrm{kg})$ were used to calculate the transfer factor(TF) of four edible plants using the following relationship [3]:

$T F=\frac{\text { activityconcentrationofdryplantsample }(\mathrm{Bq} / \mathrm{kg})}{\text { activityconcentrationof drysoilsample }(\mathrm{Bq} / \mathrm{kg})}$

\section{Results and Discussion}

Table 1: shows the soil and plant sample activity concentrations, and the soil-plant transfer factor. The values in this table are mean \pm standard deviation. The results showed that exposure to one hour and three hours for soil and plant samples respectively are suitable for obtaining clear spectra which in turn will be used for estimation of the activity concentration.

Moreover, the present study has shown that the highest concentration in soil for U-238 is 27.627 $\pm 5.525 \quad(\mathrm{~Bq} / \mathrm{kg})$, for $\mathrm{Th}-232$ is $18.347 \pm 3.091$ and for $\mathrm{K}-40$ is $94.727 \pm 20.840$ in white bean, red bean and the zucchini, respectively.

In comparison to the soil concentration values of $[1,19,20]$, the current results show the average values $19.572 \pm 3.914, \quad 16.901 \pm 2.845$ and $87.142 \pm 19.171$ of U-238, Th-232 and K-40, respectively, which represent the significant low value as reported in Table 1.

The current results show that the average values were lower than the vegetables concentration values previously reported [21,22] as shown in Table (1), where the average radioactivity in vegetables ranged from $1.322 \pm 0.238 \mathrm{~Bq} / \mathrm{kg}$ for U238 , for $0.784 \pm 0.133$ Th-232 and 3.674 \pm 0.629 for $\mathrm{K}-40$, respectively.
The uptake of U-238 and Th-232 is lower than of $\mathrm{K}-40$, that might be due to fertilization with K-40, where potassium is considered a macronutrient for plants and is the most abundant cation within plant cells which may lead to no changes in their activity values. The range of transfer values of $\mathrm{U}-238$ is from 0.034 to 0.097 , for Th- 232 is 0.025 to 0.046 and for K-40 is 0.037 to 0.051 as shown in Figure. (2).

Interestingly, the results demonstrate that the lowest concentration value of U-238, Th-232 and $\mathrm{K}-40$ in zucchini is $0.607 \pm 0.109,0.437 \pm 0.074$ and $3.527 \pm 0.423$ respectively. Therefore, zucchini exhibits a lower transfer coefficient than the other plants as indicated Figure. (2).

Table (2) shows the results obtained from the soil samples by calculating the absorbed dose rates (D), radium equivalent activities $\left(\mathrm{Ra}_{\mathrm{eq}}\right)$, external hazard indexes (Hex), internal hazard indexes (Hin), and annual effective dose (AED) indoor and outdoor for the U-238, Th-232 and K-40 radionuclides.

In the meantime, it is stated that the Radium equivalent activity $\left(R a_{e q}\right)$ has been utilized for the measurement of the hazard of radioactivity in environmental materials. It is important to note that the results documented that the value of the radium equilibrium index is $50.450 \mathrm{~Bq} / \mathrm{kg}$ which is considered as the safe level of the public when compared with the Organization of Economic Cooperation and Development (OECD) [23], where, the value of $370 \mathrm{~Bq} / \mathrm{kg}$ is the ideal value for exposure to the public as it is equal to $1.5 \mathrm{mSv} /$ year.

According to the UNSCEAR report [1], the dose rate in outdoor air from terrestrial gamma rays under normal conditions is approximately $60 \mathrm{nGy} /$ $\mathrm{h}$ for a population weighted value. Therefore, a low estimated mean value in the current study $(22.884 \mathrm{nGy} / \mathrm{h})$ was detected and is even lower when compared to the values that were obtained by [20].

In comparison to the worldwide average, the annual effective dose is $0.48 \mathrm{mSv}$ and the results for individual countries are $0.3-0.6 \mathrm{mSv}$ range of [1]. The current research work shows the average values of outdoor and indoor are $0.028 \mathrm{mSv}$ and 0.112 , respectively which is significantly low.

Table (2) also illustrates the average values of $H_{e x}$ and $H_{\text {in }}$ which are less than one. Hence the soil is safe for planting. Moreover, The European Commission (EC) approved an index called the gamma index (Iy) to verify whether the material is 
safe or not. However, in the present study, the average value of soil is 0.358 which is clearly less than one conforming the safety of the soil.

Plants and open-air vegetables can be affected by the earth release of radionuclides (U-238, Th-232 and K-40), resulting in radioactive contamination. Thus, radionuclides tend to be detected from leafy vegetables especially the ones with large leafy parts in the early phase after a nuclear accident. Background levels of radionuclides (natural or artificial) in foods vary and are dependent on several factors, including which part of plant the customers eat, the type of food and the geographic region where the food has been produced. The common radionuclides in food are K-40, Ra-226, U-238 and their associated progeny. In general, K40 is the most commonly occurring natural radioisotope. Other natural radioisotopes exist in much lower activity concentrations, and originate from the decay of thorium and uranium [24].

Table (3) illustrates the results obtained from the plant samples in this study regarding the calculated absorbed dose rates (D) average is 1.237 $\mathrm{nGy} / \mathrm{h}$, radium equivalent activities $\left(\mathrm{Ra}_{\mathrm{eq}}\right)$ average is $2.726 \mathrm{~Bq} / \mathrm{kg}$, external hazard indexes (Hex) average is 0.007 which is less than one, internal hazard indexes (Hin) average is 0.11 also is less than one, moreover the gamma index (Iy) is less than one. The annual effective dose (AED) indoor and outdoor for the U-238, and Th-232 and K-40 radionuclides are very low 0.006 and 0.007 respectively. All these parameters are in the safe level of hazard in the case of indoor and outdoor hazards as compared to the data reported by the UNSCEAR[25].

The research investigation documented that the annual absorbed effective dose for workers outdoor ( 8 hour in the farm and affected to the radiation) is very low $0.002 \mathrm{mSv}$ and in door (green house) is $0.006 \mathrm{mSv}$. Moreover, the results were confirmed by the estimation Hex, Hin and gamma index where all of these parameters were less than one. Hence the leaves of plant are not counted as hazard source.

Table (1): Average activity concentrations \pm standard deviation of U-238 and Th-232 and K-40 of soil and edible plant samples in $(\mathrm{Bq} / \mathrm{kg})$ collected from different locations in Sharqia site

\begin{tabular}{|c|c|c|c|c|c|c|c|}
\hline \multirow[t]{2}{*}{ soil } & \multicolumn{3}{|c|}{$\begin{array}{l}\text { Mean soil concentration } \pm \mathrm{SD} \\
(\mathrm{Bq} / \mathrm{kg})\end{array}$} & \multirow[t]{2}{*}{$\begin{array}{l}\text { Plants } \\
\text { (vegetables) }\end{array}$} & \multicolumn{3}{|c|}{$\begin{array}{l}\text { Mean plant concentration } \pm \text { SD } \\
(\mathrm{Bq} / \mathrm{kg})\end{array}$} \\
\hline & U-238 & Th-232 & K-40 & & U-238 & Th-232 & K-40 \\
\hline White bean & $\begin{array}{l}16.637 \\
\pm 3.327\end{array}$ & $\begin{array}{l}14.843 \\
\pm 2.495\end{array}$ & $\begin{array}{l}71.217 \\
\pm 15.668\end{array}$ & White bean & $\begin{array}{l}1.607 \\
\pm 0.289\end{array}$ & $\begin{array}{l}0.946 \\
\pm 0.161\end{array}$ & $\begin{array}{l}3.637 \\
\pm 0.546\end{array}$ \\
\hline Red bean & $\begin{array}{l}16.007 \\
\pm 3.201\end{array}$ & $\begin{array}{l}18.347 \\
\pm 3.091\end{array}$ & $\begin{array}{l}89.737 \\
\pm 19.742\end{array}$ & Red bean & $\begin{array}{l}1.387 \\
\pm 0.250\end{array}$ & $\begin{array}{l}1.157 \\
\pm 0.197\end{array}$ & $\begin{array}{l}3.547 \\
\pm 0.709\end{array}$ \\
\hline Cucumber & $\begin{array}{l}27.627 \\
\pm 5.525\end{array}$ & $\begin{array}{l}17.127 \\
\pm 2.883\end{array}$ & $\begin{array}{l}92.887 \\
\pm 20.435\end{array}$ & Cucumber & $\begin{array}{l}1.687 \\
\pm 0.304\end{array}$ & $\begin{array}{l}0.597 \\
\pm 0.101\end{array}$ & $\begin{array}{l}3.987 \\
\pm 0.837\end{array}$ \\
\hline Zucchini & $\begin{array}{l}18.017 \\
\pm 3.603\end{array}$ & $\begin{array}{l}17.287 \\
\pm 2.910\end{array}$ & $\begin{array}{l}94.727 \\
\pm 20.840\end{array}$ & Zucchini & $\begin{array}{l}0.607 \\
\pm 0.109\end{array}$ & $\begin{array}{l}0.437 \\
\pm 0.074\end{array}$ & $\begin{array}{l}3.527 \\
\pm 0.423\end{array}$ \\
\hline Average & $\begin{array}{l}19.572 \\
\pm 3.914\end{array}$ & $\begin{array}{l}16.901 \\
\pm 2.845\end{array}$ & $\begin{array}{l}87.142 \\
\pm 19.171\end{array}$ & Average & $\begin{array}{l}1.322 \\
\pm 0.238\end{array}$ & $\begin{array}{l}0.784 \\
\pm 0.133\end{array}$ & $\begin{array}{l}3.674 \\
\pm 0.629\end{array}$ \\
\hline Ref. [1] & 35 & 30 & 400 & Ref. [21] & 5.21 & 4.76 & 186.15 \\
\hline Ref. [18] & 85.8 & 51.1 & 771.6 & Ref. [22] & $2.2-36.8$ & $4.1-30.1$ & $700-2520$ \\
\hline Ref. [19] & 24.5 & 51.8 & 344.9 & & & & \\
\hline
\end{tabular}




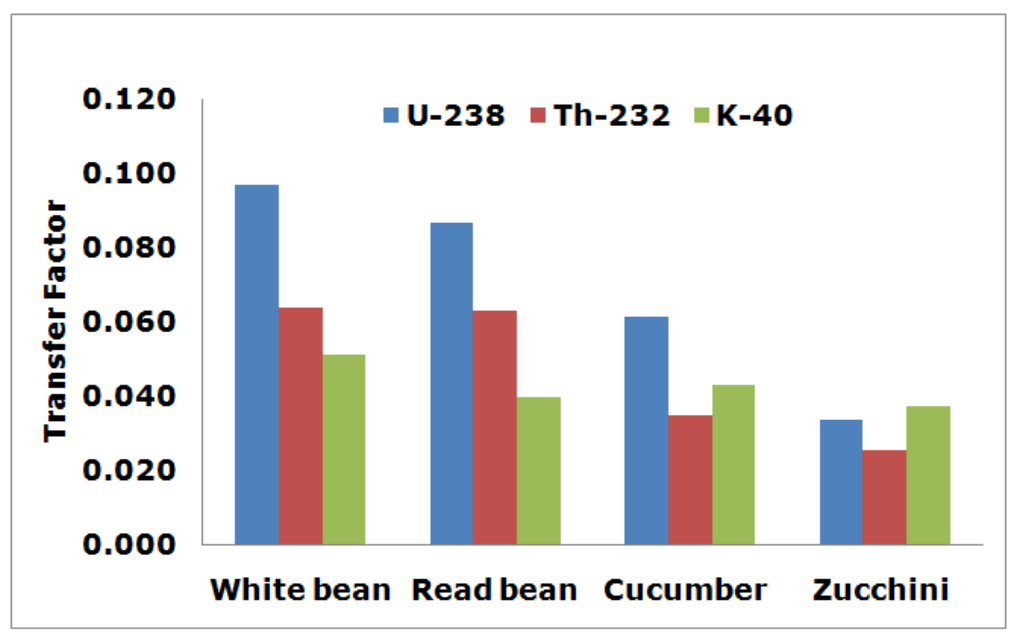

Figure (2): shows the transfer factor of U-238, Th-232 and K-40 of four daily edible foods (white bean, red bean, cucumber and zucchini)

Corresponding author: elywa2006@gmail.com

DOI: 10.21608/ajnsa.2019.5754.1132

(C) Scientific Information, Documentation and Publishing Office (SIDPO)-EAEA 
Table (2): Absorbed dose rate, annual effective dose rate and radiation hazard indices for soil samples

\begin{tabular}{cccccccc}
\hline $\begin{array}{c}\text { Soil } \\
\text { samples }\end{array}$ & $\begin{array}{c}\mathrm{Ra}_{\mathrm{eq}} \\
(\mathrm{Bq} / \mathrm{kg})\end{array}$ & $\begin{array}{c}\mathrm{D} \\
(\mathrm{nGy} / \mathrm{h})\end{array}$ & $\begin{array}{c}\mathrm{AED}(\text { out }) \\
\mathrm{mSv}\end{array}$ & $\begin{array}{c}\mathrm{AED}(\mathrm{in}) \\
\mathrm{mSv}\end{array}$ & $\begin{array}{c}\mathrm{Hex} \\
(\mathrm{Bq} / \mathrm{kg})\end{array}$ & $\begin{array}{c}\mathrm{Hex} \\
(\mathrm{Bq} / \mathrm{kg})\end{array}$ & $\mathrm{Ir}$ \\
\hline White bean & 43.345 & 19.621 & 0.024 & 0.096 & 0.117 & 0.117 & 0.307 \\
Read bean & 49.152 & 22.218 & 0.027 & 0.109 & 0.133 & 0.133 & 0.350 \\
Cucumber & 59.270 & 26.981 & 0.033 & 0.132 & 0.160 & 0.160 & 0.417 \\
Zucchini & 50.031 & 22.715 & 0.028 & 0.111 & 0.135 & 0.135 & 0.356 \\
Average & $\mathbf{5 0 . 4 5 0}$ & $\mathbf{2 2 . 8 8 4}$ & $\mathbf{0 . 0 2 8}$ & $\mathbf{0 . 1 1 2}$ & $\mathbf{0 . 1 3 6}$ & $\mathbf{0 . 1 3 6}$ & $\mathbf{0 . 3 5 8}$ \\
\hline
\end{tabular}

Table (3): Radium equivalent, absorbed dose rate, annual effective dose rate and Radiation Hazard Indices for plant samples

\begin{tabular}{cccccccc}
\hline Plant sample & $\mathbf{R a}$ eq $(\mathbf{B q} / \mathbf{k g})$ & $\mathbf{D}(\mathbf{n G y} / \mathbf{h})$ & $\begin{array}{c}\mathbf{A E D}(\mathbf{o u t}) \\
\mathbf{m S v}\end{array}$ & $\begin{array}{c}\mathbf{A E D}(\mathbf{i n}) \\
\mathbf{m S v}\end{array}$ & $\mathbf{H e x}(\mathbf{B q} / \mathbf{k g})$ & Hin $(\mathbf{B q} / \mathbf{k g})$ & $\mathbf{I r}$ \\
\hline White bean & 3.239 & 1.465 & 0.002 & 0.007 & 0.009 & 0.013 & 0.023 \\
Red bean & 3.314 & 1.487 & 0.002 & 0.007 & 0.009 & 0.013 & 0.023 \\
Cucumber & 2.847 & 1.306 & 0.002 & 0.006 & 0.008 & 0.012 & 0.020 \\
Zucchini & 1.503 & 0.691 & 0.001 & 0.003 & 0.004 & 0.006 & 0.011 \\
Average & $\mathbf{2 . 7 2 6}$ & $\mathbf{1 . 2 3 7}$ & $\mathbf{0 . 0 0 2}$ & $\mathbf{0 . 0 0 6}$ & $\mathbf{0 . 0 0 7}$ & $\mathbf{0 . 0 1 1}$ & $\mathbf{0 . 0 1 9}$ \\
\hline
\end{tabular}

\section{Conclusion}

The study confirms that the uptake and activity concentration of U.238 and Th-232 were significantly low compared to K-40 radionuclide in all the soil and edible plant samples. One important outcome of this study is that the activity concentrations of radionuclides in Sharqia Governorate either in soil or in plant samples are under the world wide values. The current values of radium equivalent, annual absorbed effective dose, indoor, outdoor absorbed dose and hazard index $\left(\mathrm{H}_{\mathrm{ex}}, \mathrm{H}_{\mathrm{in}}\right.$ and $\left.\mathrm{I}_{\gamma}\right)$ shows that the soil is safe for agriculture. Interestingly, the results demonstrate that there is no health risk to eat these edible plants.

\section{Acknowledgements}

I would like to thank Prof. Dr. Hoda Omar and Prof. Dr. Fawzia Mubarak, Egyptian Atomic Authority for the constant encouragement and moral support for his research work.

\section{References}

1- UNSCEAR. (2000) Sources and effects of ionizing radiation; United Nations Scientific Committee on the Effects of Atomic Radiation: New York, USA, United Nations Publication.
2- Ahmed, N.; Jaafar, M. S.; Bakhash, M.; Rahim, M.( 2015) An overview on measurements of natural radioactivity in Malaysia, Journal of Radiation Research and Applied Sciences,8 (1), 136-141.

3- Elywa, M.; Mubarak, F.; Omar, H.; Mansour, N.; Selem, E.; Marwaan, N. (2016) Determination of Soil-Plant Transfer Factor of Edible Plants Grown in a Contaminated Soil with Europium - 152, Middle East Journal of Scientific Research,24 (10), 3278-3283.

4- IAEA. (2006)Environmental consequences of the Chernobyl accident and their remediation: twenty years of experience, International Atomic Energy Agency.

5- UNSCEAR.( 1982) Sources and effects of ionizing radiation.; United Nations Scientific Committee on the Effects of Atomic Radiation: New York, USA, United Nations Publication.

6- Shtangeeva, I. (2010)Uptake of uranium and thorium by native and cultivated plants, Journal of Environmental Radioactivity,101 (6), 458-463.

7- Ehlken, S.; Kirchner, G. (2002)Environmental processes affecting plant root uptake of radioactive trace elements and variability of transfer factor data, Journal of Environmental Radioactivity,58, 97-112.

8- Chakraborty, S.; Azim, R.; Rezaur Rahman, A.; Sarker, R.( 2013) Radioactivity Concentrations in Soil and Transfer Factors of Radionuclides from Soil to Grass and Plants in the Chittagong City of 
Bangladesh, Journal of Physical Science,24 (1), 95 $-113$.

9- Sheppard, S.( 2011)Review of "Handbook of Parameter Values for the Prediction of Radionuclide Transfer in Terrestrial and Freshwater Environments". IAEA Technical Reports Series No 472, 2010, journal of Environmental Radioactivity,102 (2), 217.

10- Koibuchi, Y. (2013) Tracing fine-grained sediment transport around Tokyo Bay using cesium-134 and cesium-137 originating from Fukushima Daiichi Power Plant, WIT Transactions on Ecology and the Environmen.

11- Ishii, K.; Fujita, A.; Toyama, S.; Terakawa, A.; Matsuyama, S.; Arai, H.; Kasahara, K. (2015) The Determination of Soil-plant Transfer Coefficients of Cesium-137 and Other Elements by $\gamma$-Ray Measurement and PIXE Analysis, for use in the Remediation of Fukushima, Physics Procedia,66, 278-286.

12- Thiry, Y.; Colle, C.; Yoschenko, V.; Levchuk, S.; Van Hees, M.; Hurtevent, P.; Kashparov, V.( 2009) Impact of Scots pine (Pinus sylvestris L.) plantings on long term (137)Cs and (90)Sr recycling from a waste burial site in the Chernobyl Red Forest, Journal of Environmental Radioactivity,100 (12), 1062-1068.

13- Mubarak, F.; Elywa, M.; Saand, E.(2017) Activity Concentration and Soil-Plant Transfer Factor of Naturally Occurring Radionuclides Around Charcoal Kilns in Egypt, World Applied Sciences Journal,35 (11), 2341- 2347.

14- UNSCEAR. (2008) Sources and effects of ionizing radiation; United Nations scientific committee on the effects of atomic radiation: New York, USA, United Nations Publication.

15- $\quad$ Saito, K.; Jacob, P. (1995) Gamma ray fields in the air due to sources in the ground. Radiation Protection Dosimetry,58, 29-45.

16- Tufail, M.; Akhtar, N.; Jaried, S.; Hamid, T.( 2007) Natural radioactivity hazards of building bricks fabrication from soil of two districts of
Pakistan, Journal of radiological protection,27, 481-492.

17- UNSCEAR. (1993) United Nations Scientific Committee on the Effects ofAtomic Radiation: Sources and Effects of Ionizing Radiation; United Nations sales publication, United Nations, New York.

18- Yehumwdah, E.;Inimbom, J. (2017) A gamma spectrometric analysis and radium equvlent activity index of water and abak; Nagiria, a baseline survey, journal of environment and earth science, 7,19-26.

19- Dizman, S.; Gorür, F. K.; Keser, R.( 2016) Determination of radioactivity levels of soil samples and the excess of lifetime cancer risk in Rize Province, Turkey, International Journal of Radiation Research,14 (3), 237 - 244.

20- Durusoy, A.; Yildirim, M. (2017) Determination of radioactivity concentrations in soil samples and dose assessment for Rize Province, Turkey. Journal of Radiation Research and Applied Sciences, 10, 348-352.

21- Abojassim, A.A.; Hady, H. N.; Mohammed. Z. B. (2016). "Natural radioactivity levels in some vegetables and fruits commonly used in Najaf Governorate, Iraq." Journal of bioenergy and food science, 3(3), 113-123.

22- Nyanda, P.B. and Nkuba, L.L.(2017) Natural Radioactivity in Vegetables from Selected Areas of Manyoni District in Central Tanzania, Physical Science International Journal, 16(2),1-10.

23- OECD. (1998) Uranium Ressources, Production Et Demande, Organisation For Economic Co-Operation And Development.

24- FAO. (2011) Nuclear accidents and radioactive contamination of foods, Food and Agriculture Organization of the United Nations.

25- UNSCEAR. (2013) Sources and effects of ionizing radiation; United Nations scientific committee on the effects of atomic radiation: New York, USA, United Nations Publication. 